\title{
WHEN THE COLD COMES
}

\author{
Be prepared.
}

\section{BY DEBORAH WALKER}

$\mathrm{B}$ efore the funeral, I send seven sealed letters to the Unwalled Cities asking them to fulfil their obligations and send their best students to the Disease University and the Quarantine Security Academy. This is not the first request I've sent. I doubt the cities will honour their responsibilities, but the sealed letters will serve their purpose. Seven seals. If I were a Doctrinist, I might find some significance in that.

Although in Isolation Theta we are, in the main part, atheists, we appreciate ceremony as much as any Earth Doctrinist. The great and the good are gathered to attend the funeral of Dr Olinda Troy, the fourteenth Commander Pathologist of our colony.

Her coffin is empty. She's donated her body to the Disease U. I'm grateful. We're short of corpses, and my labs need bodies to test the latest antivirals. The InterferonZeconaril hybrid may, given time, prove effective.

When it's my turn to speak, I talk about an old Earth fable. The feckless grasshopper spent her summer playing the mandolin, while the ant toiled to build a store of food. Winter comes, as it always does, and in the cold the hungry grasshopper begs the ant for food and is refused. The food is for the ant and for her family. Hard work, sacrifice and planning are the ant's virtues.

"Dr Troy was an ant," I tell the congregation. "When the cold virus, Rhinovirus HRV-A488 mutated into the Bleeding Eyes serotype, she was ready. She activated the city walls. She marshalled the quarantine police. She enforced the daily testing regime, and expelled the infected: man and woman and child. She ensured our survival. Only through the harshest measures can we endure the Cold. And afterwards, she continued the fight, developing weapons against the myriad serotypes that wait for us. Through her will,

\section{DNATURE.COM}

Follow Futures:

3 @NatureFutures

f go.nature.com/mtoodm she saved this colony. As the fifteenth Commander Pathologist, I will do the same, if called to do so."
My eulogy is received in silence. There is a new ethos in the city. The next speaker tells it. "Compassion is the hallmark of this colony. We pity the scientists who genemodded the common-old viruses. We pity the doctors who undertook the clinical trial. We pity the lab workers who manufactured

and genemodded to have fatal potentiality. Repeated mutations, owing to low-fidelity replication and frequent recombination, mean that at any time antigenic shift may occur, and a new, fatal pandemic may arise. Witness the previous epidemics: Bleeding Eyes, The Judders, Heart Halt, Dry Dust Brain, The Weeping Trembles.

We cannot vaccinate against 500 constantly mutating strains, but I believe the antiviral hybrids will eventually generate a cure.

The grasshoppers, however, want to divert our resources to other things. Wouldn't it be fine to build another ship, they argue? To go off planet.

Of the walled cities we built before the attack, only Theta stands. Our colony ship was stationed at Epsilon. In the chaos of our first pandemic, the citizens of Epsilon fled the planet. But they took the Cold aboard, virions harboured in the air they breathed.

We never heard from the colony ship. Why would a new ship be any different?

I walk slowly to the labs. Sometimes, and this is a fanciful conceit, I imagine the

the viruses. We pity the physicists who plotted the course of the bioweapon. We pity the Doctrinist Senate that approved the decision. We pity every Doctrinist man and woman who condoned that act to send the bioweapon hurtling after the people fleeing Earth. We pity them all."

It's a grasshopper sentiment, as Dr Troy often remarked. She's dead. She'll not have to witness another epidemic. There is my pity.

The service ends, the grasshoppers move out quickly. We ants are slower, older.

I pass two grasshoppers. The woman clings to her husband. "I can't believe Earth sent the Cold after us. What hatred they had."

"I pity them," says the man sanctimoniously.

Pity is a fine thing. But do the grasshoppers think it will save them? They're lulled because the Cold has been quiet for half a century. Yet there is no vaccination against the Cold, and little to no crossprotection against the serotypes. Earth sent us at least 500 serotypes, highly contagious
Cold as an entity. A spectre that's staying its hand. It knows that if it attacks in 20 years, it will find the cities overflowing with grasshoppers, full of pity, unwilling to do what is necessary. The Cold tires of the contest and in a few decades it will have its endgame.

A fancy only. A virus has no will. There was only the will of the Doctrinists who created it and set out to destroy us non-believers. And there is only my will that will keep the game in play.

I have sent seven sealed letters. When the seals are opened, a new pandemic will be born. The Cold will come, killing grasshoppers and ants alike. But I will be here. I will ensure that we endure. I will set a new generation of ants working towards the cure.

I am the sender of the seals. I am the harbinger of the plague. I am the doctor who sends Cold into our world.

Do not pity me.

Find Deborah in the British Museum trawling the past for future inspiration. 